\title{
Karakteristik Life Time dan Efisiensi Modul Surya Berbasis Pewarna Menggunakan Interkoneksi Seri
}

\section{Life Time and Efficiency Characteristics of Dye-based Solar Module Using Series Interconnection}

\author{
Iqbal Febriana ${ }^{\text {a, }}$, Lia Muliani ${ }^{\text {b }}$, Budi Mulyanti ${ }^{\mathrm{a}}$ \\ Departemen Pendidikan Teknik Elektro, Universitas Pendidikan Indonesia \\ Jalan Setiabudi No. 229 Bandung 40154, Indonesia \\ Pusat Penelitian Elektronika dan Telekomunikasi, Lembaga Ilmu Pengetahuan Indonesia \\ Komplek LIPI Gedung 20 Lantai 4, Jl Sangkuriang, Bandung 40135, Indonesia
}

\begin{abstract}
Abstrak
Sel surya berbasis pewarna atau yang dikenal dengan dye-sensitized solar cell (DSSC) merupakan sel surya generasi baru yang bekerja berdasarkan photoelectrochemical. Proses absorpsi cahaya dilakukan oleh molekul pewarna (dye) dan proses pemisahan muatan oleh bahan semikonduktor anorganik (dalam penelitian ini digunakan $\mathrm{TiO}_{2}$ ). Dalam penelitian ini dilakukan pabrikasi modul surya menggunakan lapisan partikel nano $\mathrm{TiO}_{2}$ (non-scattering) dan menggunakan campuran lapisan partikel nano $\mathrm{TiO}_{2}$ dengan lapisan partikel sub-mikron $\mathrm{TiO}_{2}$ (scattering). Tujuan penelitian ini adalah untuk mengetahui waktu hidup (life time) dan efisiensi modul surya dengan bahan yang berbeda. Pabrikasi modul surya ini menggunakan teknik screen printing. Karakteristik life time diperoleh dari hasil pengukuran I-V yang dilakukan secara manual menggunakan lampu LED 15 Watt dengan intensitas $40 \mathrm{~mW} / \mathrm{cm}^{2}$. Pengujian life time dilakukan selama $500 \mathrm{jam}$, dan hasilnya menunjukkan bahwa modul surya dengan lapisan scattering dapat mempengaruhi karakteristik life time namun efisiensi yang didapatkan kurang baik yaitu sebesar $0,31 \%$ sedangkan modul surya dengan lapisan non-scattering menunjukkan efisiensi yang baik yaitu sebesar $1,83 \%$ namun karakteristik life time yang kurang baik.
\end{abstract}

Kata kunci: sel surya berbasis pewarna, scattering, karakteristik I-V, life time.

\section{Abstract}

Dye-based solar cells, known as dye-sensitized solar cell (DSSC) is a new generation of solar cells that works based on photoelectrochemical. The light absorption and charge separation processes are done by dye molecule and anorganic semiconductor material (eq $\mathrm{TiO}_{2}$ ), respectively. In this research, the fabrication of solar modules uses a TiO ${ }_{2}$ nanoparticles (nonscattering) layer and uses a mixture of nano-particles of $\mathrm{TiO}_{2}$ layer with a layer of sub-micron particles of $\mathrm{TiO}_{2}$ (scattering). The purpose of this study is to determine the life time and the efficiency of solar modules with different materials. This solar module fabrication utilizes screen printing techniques. Lifetime characteristics obtained from the I-V measurements were performed manually using a 15 Watt LED light with an intensity of $40 \mathrm{~mW} / \mathrm{cm}^{2}$. Tests performed during the 500-hour lifetime, and the results show that the scattering solar modules may affect the characteristics of the life time but poor efficiency obtained as high as $0.31 \%$ while the non-scattering solar module showed good efficiency as high as $1.83 \%$, but the characteristics of life time is not good.

Keywords: dye-based solar cells, scattering, I-V characteristic, life time.

\section{Pendahuluan}

Sel surya berbasis pewarna atau yang dikenal dengan dye-sensitized solar cell (DSSC) merupakan sel surya generasi baru yang bekerja berdasarkan photoelectrochemical, di mana proses absorpsi cahaya dilakukan oleh molekul pewarna (dye) dan proses pemisahan muatan oleh bahan semikonduktor anorganik yaitu $\mathrm{TiO}_{2}$. Lapisan hamburan berbagai struktur, termasuk pusat hamburan dan lapisan atas hamburan, sudah secara efektif digunakan untuk meningkatkan mengumpulkan cahaya (light harvesting) yang semua itu menunjukkan efisiensi sel surya [1]. Beberapa

\footnotetext{
* Corresponding Author.

Email: febriana.iqbal@gmail.com

Received: March 27, 2015; Revised: April 4, 2015

Accepted: June 4, 2015

Published: June 30, 2015

(C) 2015 PPET - LIPI

doi : 10.14203/jet.v15.28-32
}

keuntungan sistem sel surya ini adalah proses pabrikasinya lebih sederhana tanpa menggunakan peralatan rumit dan mahal sehingga biaya pabrikasinya lebih murah [2]. Efisiensi konversi sistem sel surya tersensitasi dye telah mencapai $10-11 \%$ [3]. Namun demikian, sel surya ini memiliki kelemahan yaitu stabilitasnya rendah karena penggunaan elektrolit cair yang mudah mengalami degradasi atau kebocoran [4]. Banyak penelitian yang telah dilakukan untuk meningkatkan kinerja DSSC seperti elektrolit padat, pensintesis baru, katalis baru dan film transparan dengan tahanan lebih rendah. Struktur sel surya ini berbentuk struktur sandwich, di mana dua elektroda yaitu elektroda $\mathrm{TiO}_{2}$ (elektroda kerja) tersensitasi dye dan elektroda counter (elektroda lawan) mengapit elektrolit. Berbeda dengan sel surya silikon, pada sel surya tersentisisasi dye, foton diserap oleh dye yang melekat pada permukaan partikel $\mathrm{TiO}_{2}$. Dalam hal ini dye bertindak sebagai donor elektron yang dibangkitkan 
ketika menyerap cahaya, mirip fungsi klorofil pada proses fotosintesis. Sedangkan lapisan $\mathrm{TiO}_{2}$ bertindak sebagai akseptor elektron yang ditransfer dari dye yang teroksidasi. Elektrolit redoks berupa pasangan iodide/triodide $\left(\mathrm{I}^{-} / \mathrm{I}_{3}^{-}\right)$bertindak sebagai mediator redoks sehingga menghasilkan proses siklus di dalam sel [5]. Prinsip kerja sel surya DSSC ditunjukkan pada gambar berikut.

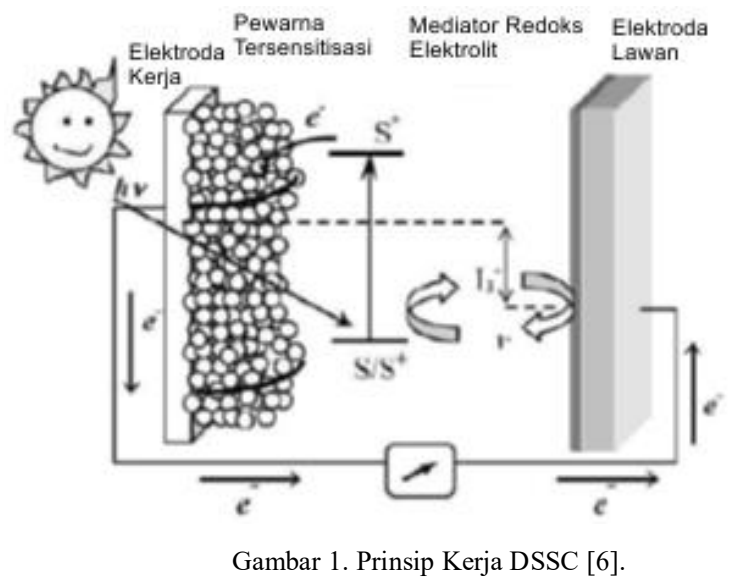

Semua pengembangan penilitian bermaksud untuk meningkatkan kinerja DSSC agar dapat digunakan dengan efisiensi yang tinggi dan stabil. Umumnya sel surya DSSC menghasilkan karakteristik tegangan sekitar 0,5-0,7 V, sehingga untuk mengaplikasikan pada perangkat elektronika yang memerlukan tegangan yang lebih tinggi, sel-sel tersebut harus dirangkai menjadi suatu modul surya. Untuk peningkatan kinerja DSSC, dalam penelitian ini akan dibuat beberapa modul surya.

Dalam penelitian ini akan dibuat modul surya berbasis pewarna yang dirangkai dengan sistim interkoneksi seri (series interconnection) untuk menghubungkan bagian antar sel satuannya. Proses pembuatan modul surya ini menggunakan teknik screen printing yang lebih mudah dan dapat dihasilkan lapisan $\mathrm{TiO}_{2}$ yang lebih homogen. Pada penelitian ini akan dibandingkan karakteristik I-V dari dua jenis modul surya dengan bahan berbeda. Modul surya dibedakan menjadi dua jenis bahan berbeda. Modul surya tanpa penghambur (non-scattering) yaitu modul surya dengan lapisan partikel nano $\mathrm{TiO}_{2}$ dan modul surya dengan penghambur (scattering) yaitu modul surya dengan lapisan partikel nano $\mathrm{TiO}_{2}$ yang ditambahkan dengan lapisan partikel sub-mikron $\mathrm{TiO}_{2}$. Karakteristik listrik dan waktu hidup (life time) diukur dan dianalisis.

\section{MetodologI}

\section{A. Desain Modul Surya}

Pada penelitian ini metode yang digunakan adalah metode eksperimen. Material utama yang digunakan berupa partikel $\mathrm{TiO}_{2}$ kristal berukuran nano (DSL 18 NR-T) dan partikel $\mathrm{TiO}_{2}$ kristal berukuran sub-mikron (WER2-O). Kedua bahan tersebut diaplikasikan untuk membuat komponen fotoelektroda dari modul surya berbasis pewarna.

Substrat yang digunakan adalah kaca konduktif TCO (transparent conducting oxide) yaitu FTO (flourine doped tin oxide) produksi Dyesol. Substrat FTO memiliki ketebalan $3 \mathrm{~mm}$ dan resistivitas bahan sebesar 8 Ohm/sq. Substrat kaca penghantar tersebut berperan sebagai pengumpul arus juga sebagai struktur pendukung sel dan lapisan pembatas antara sel dengan udara terbuka. Ada dua jenis substrat yang digunakan, satu menjadi elektroda kerja dan yang lain menjadi elektroda lawan. Pada substrat elektroda lawan menggunakan kaca biasa yang dilapisi dengan platina menggunakan metode sputtering DC tipe ARC-12M. Kaca yang digunakan untuk elektroda lawan harus direndam terlebih dahulu dengan larutan $\mathrm{HF}$ (Hydrofluoric acid) untuk mengikis lapisan kaca agar platina dapat menempel dengan baik.

Desain modul surya yang digunakan dalam penelitian ini adalah desain yang telah dibuat pada penelitian sebelumnya [7] yang dapat dilihat pada Gambar 2, yaitu modul surya yang terdiri dari tiga sel tunggal berukuran $9,8 \times 1 \mathrm{~cm}$ yang diinterkoneksikan secara seri. Ukuran luas total yang digunakan pada penelitian ini adalah $9,8 \times 3 \mathrm{~cm}$.

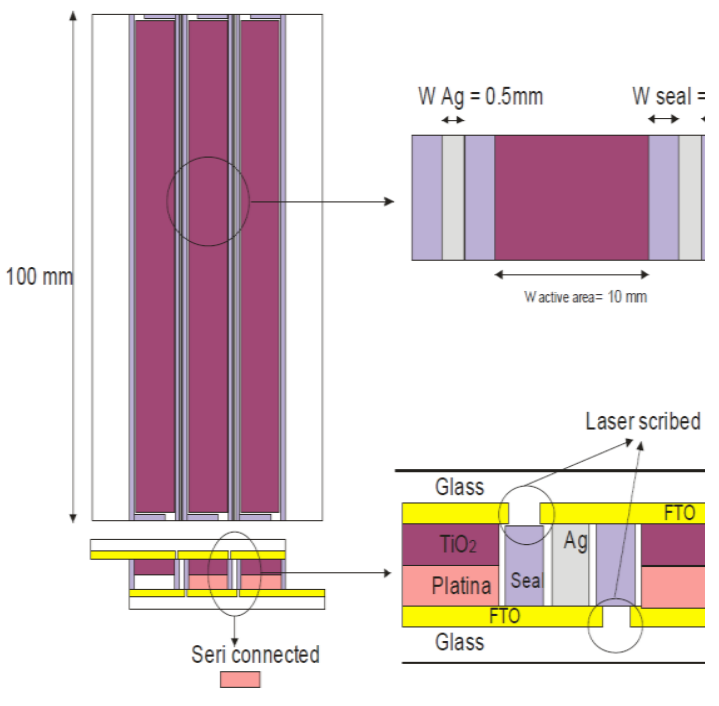

Gambar 2. Desain Modul Surya [7].

\section{B. Proses Pabrikasi Modul Surya}

Proses pabrikasi modul surya yang dilakukan dalam penelitian ini dapat dilihat pada Gambar 3.

Tahapan pabrikasi sel surya berbasis pewarna di

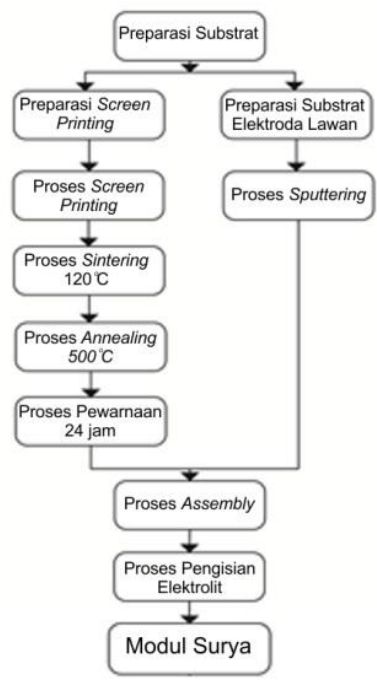

Gambar 3. Proses Pabrikasi Modul Surya. 
atas merupakan tahapan secara umum. Terdapat beberapa perlakuan yang berbeda pada masing-masing modul surya yang dibuat seperti penambahan $\mathrm{TiO}_{2}$ reflektor yang memiliki ukuran partikel 200-300 nm yang berfungsi sebagai scattering pada salah satu modul surya yang dibuat. Penggunaan $\mathrm{TiO}_{2}$ scattering pada penelitian ini menggunakan teknik pelapisan scattering di atas lapisan nano partikel $\mathrm{TiO}_{2}$.

Teknik screen printing yang digunakan dalam penelitian ini digunakan untuk mencetak pasta pada permukaan substrat sesuai pola screen. Teknik screen printing sama halnya dengan teknik penyablonan pada kaos. Teknik screen printing digunakan untuk mencetak pasta-pasta $\mathrm{TiO}_{2}$, silver, dan glass frit pada substrat.

Dalam penelitian ini dibuat 2 jenis modul dengan bahan yang berbeda, masing-masing jenis dibuat 2 modul untuk menghindari kegagalan pada saat pabrikasi modul. Pada pabrikasi modul surya, keempat substrat dilapisi dengan lapisan partikel nano $\mathrm{TiO}_{2}$ namun pada dua substrat ditambahkan dengan lapisan partikel submikron $\mathrm{TiO}_{2}$ sebagai lapisan scattering. Untuk penguatan (annealing) pasta yang telah dicetak pada substrat elektroda kerja digunakan mesin RTC (Radiant Technology Conveyer) dengan suhu $500{ }^{\circ} \mathrm{C}$. Proses pewarnaan dilakukan setelah proses annealing, proses pewarnaan dilakukan selama 24 jam dengan cara merendam elektroda kerja dalam larutan dye Z907 produksi Dyesol pada suhu ruang.

Assembly menggunakan struktur sandwich. Proses assembly dilakukan setelah elektroda lawan dan elektroda kerja telah siap. Pada tahap ini elektroda lawan ditambahkan pasta silver yang bertujuan untuk menyatukan elektroda kerja dan elektroda lawan menjadi satu ikatan interkoneksi seri, proses ini kembali menggunakan sistim screen printing untuk mencetak pasta silver. Pada elektroda kerja ditambahkan pasta glass frit sebagai perekat kedua elektroda. Pengisian elektrolit dilakukan setelah kedua elektroda menempel dengan baik. Pada proses pengisian elektrolit, larutan yang digunakan adalah larutan Elektrolit EL-SGE buatan Dyesol. Larutan disuntikan atau menggunakan vacuum dimasukan pada celah di setiap sel. Setelah terisi elektrolit, celah tersebut ditutup menggunakan glass frit.

Modul surya yang dihasilkan diukur karakteristik kurva I-V secara manual, yaitu menggunakan lampu LED 15 Watt yang diatur pada intensitas cahayanya menggunakan photoresistor radiometer sebesar 40 $\mathrm{mW} / \mathrm{cm}^{2}$. Selanjutnya dibuat rangkaian untuk mengukur karakteristik I-V menggunakan modul resistor yang dirangkai seri dengan multimeter. Kabel probe positif dihubungkan pada substrat yang terlapisi platina sedangkan kabel probe negatif dihubungkan pada substrat yang terlapisi $\mathrm{TiO}_{2}$.

\section{III.}

\section{Hasil dan Pembahasan}

Modul surya berbasis pewarna yang telah melalui proses pabrikasi kemudian dilakukan pengujian. Pengujian modul surya dilakukan melalui pengukuran karakteristik kurva I-V untuk melihat karakteristik dari masing-masing modul surya. Seperti yang telah dijelaskan, modul resistor dan multimeter yang dirangkai dengan modul surya, diterangi lampu LED 15
Watt dengan intensitas cahaya $40 \mathrm{~mW} / \mathrm{cm}^{2}$ seperti ditunjukkan pada Gambar 4.

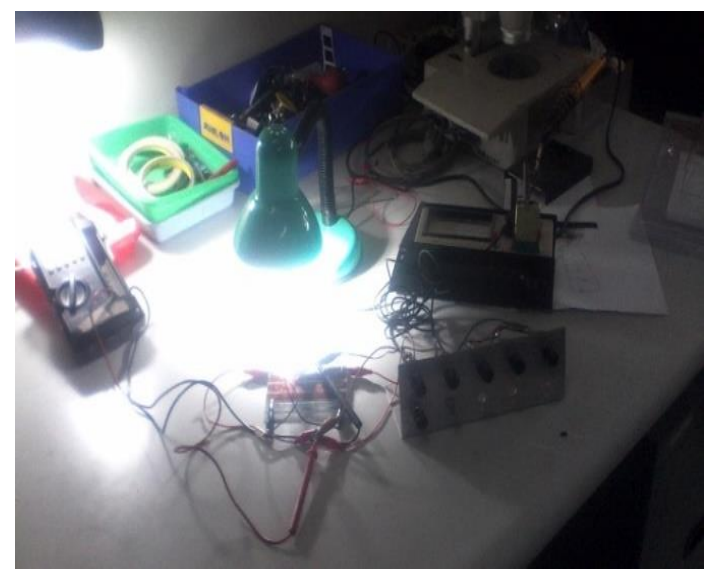

Gambar. 4. Rangkaian Uji Karakteristik Hasil.

Pada pengujian karakteristik yang dilakukan dapat diketahui nilai arus dan tegangan modul surya. Untuk mendapatkan nilai daya $(P)$ dan efisiensi $(\eta)$ dapat menggunakan Persamaan 1 dan 2 berikut,

$$
\begin{gathered}
P=V \times I \\
\eta=\frac{P \text { out }}{P \text { in }}
\end{gathered}
$$

Daya merupakan nilai laju hantaran energi listrik sedangkan efisiensi adalah nilai acuan global untuk menentukan kualitas modul surya.

Proses pengujian dilakukan dalam beberapa kali pengujian, karena untuk mendapatkan hasil dari karakteristik life time modul surya tidak dapat dilakukan hanya dengan satu kali pengujian. Dalam penelitian ini dilakukan 6 kali pengujian hingga life time modul surya mencapai 500 jam. Gambar 4 adalah gambar kurva I-V untuk pengukuran awal (0) jam.

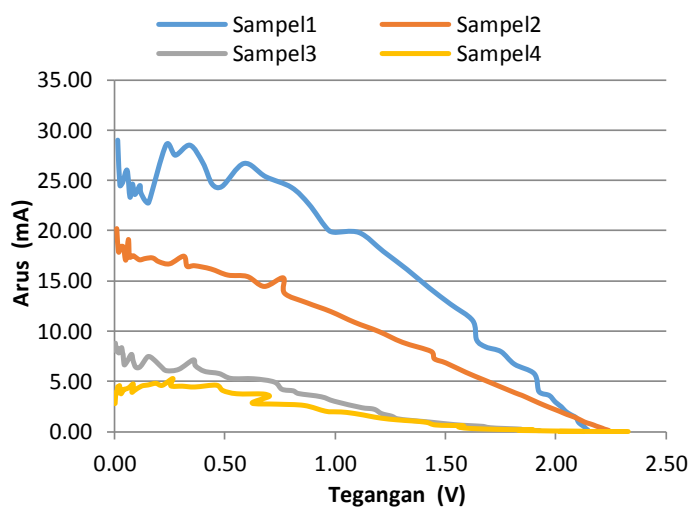

Gambar 5. Kurva I-V Pengukuran Awal (0 Jam).

Tabel 1

DATA VOC DAN ISC PADA PENGUKURAN AWAL

\begin{tabular}{|l|c|c|c|c|}
\hline \multicolumn{1}{|c|}{ Sampel } & $\mathbf{V}_{\mathbf{O C}}(\mathbf{V})$ & $\mathbf{I}_{\mathbf{S C}}(\mathbf{m A})$ & $\mathbf{P m}(\mathbf{m W})$ & $\boldsymbol{\eta}(\boldsymbol{\%})$ \\
\hline $\begin{array}{l}\text { Sampel 1 (non- } \\
\text { scattering) }\end{array}$ & 2,15 & 22,5 & 21,96 & 1,83 \\
\hline $\begin{array}{l}\text { Sampel 2 (non- } \\
\text { scattering) }\end{array}$ & 2,27 & 16,7 & 11,94 & 1 \\
\hline $\begin{array}{l}\text { Sampel 3 } \\
\text { (scattering) }\end{array}$ & 2,28 & 4,80 & 3,57 & 0,31 \\
\hline $\begin{array}{l}\text { Sampel 4 } \\
\text { (scattering) }\end{array}$ & 2,34 & 3,31 & 2,52 & 0,21 \\
\hline
\end{tabular}


Dari gambar dan tabel data pengukuran awal (0 jam) di atas memperlihatkan bahwa sampel 1 (non-scattering) menunjukkan karakteristik yang paling baik juga menghasilkan daya maksimal (Pm) sebesar 21,96 mW dan efisiensi $(\eta)$ sebesar $1,83 \%$. Sementara pada sampel 4 menunjukkan karakteristik yang paling rendah dengan daya maksimal $(\mathrm{Pm})$ sebesar 2,52 $\mathrm{mW}$ dan efisiensi $(\eta)$ sebesar $0,21 \%$.

Pada proses pengujian life time modul surya selanjutnya, beberapa sampel modul surya mengalami kebocoran elektrolit karena kegagalan pada proses assembly. Modul surya yang mengalami kebocoran adalah modul surya sampel 1 (non-scattering) dan modul surya sampel 4 (scattering) seperti ditunjukkan pada Gambar 6. Terjadinya kebocoran pada beberapa sampel modul surya membuat penelitian hanya dilakukan terhadap sampel yang kondisinya masih baik atau tidak mengalami kebocoran, yaitu modul surya sampel 2 (non-scattering) dan modul surya sampel 3 (scattering).

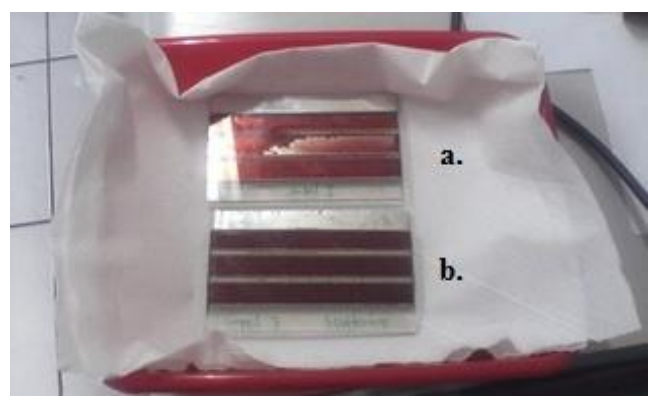

Gambar 6. (a) Sampel 1 yang Mengalami Kebocoran, (b) Sampel 3 yang Tidak Mengalami Kebocoran.

Pengukuran dilakukan hingga 500 jam untuk mendapatkan karakteristik life time modul surya. Kurva $\mathrm{I}-\mathrm{V}$ pengukuran modul surya sampel 2 (non-scattering) dapat dilihat pada Gambar 7 dan modul surya sampel 3 (scattering) dapat dilihat pada Gambar 8.

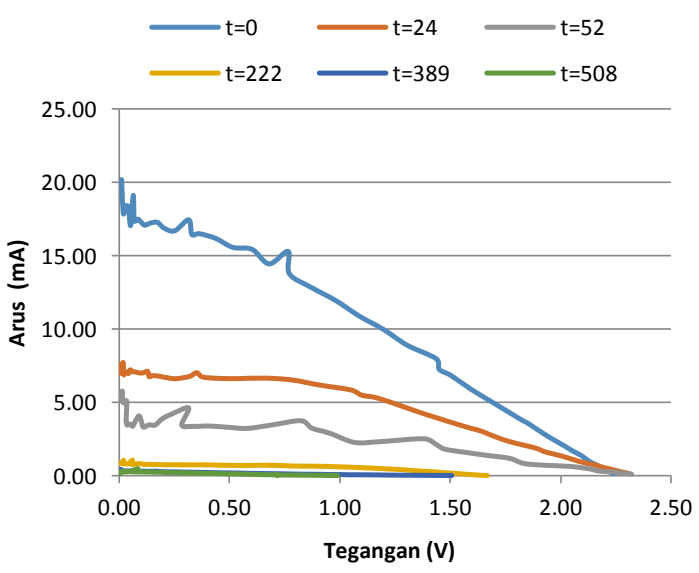

Gambar 7. Kurva I-V Life Time Sampel 2 (Non-Scattering).

Gambar 7 menjelaskan karakteristik life time modul surya sampel 2 (non-scattering), dapat dilihat bahwa grafik menunjukkan karakteristik life time yang sangat baik pada awal pengujian namun mengalami penurunan yang drastis setelah pengujian 24 jam juga terhadap pengujian lainnya hingga pengujian 500 jam. Gambar 8 menjelaskan karakteristik life time modul surya sampel
3 (scattering), dapat dilihat bahwa grafik menunjukkan karakteristik life time yang cenderung stabil terhadap penurunannya yang bertahap hingga 500 jam pengujian modul surya.

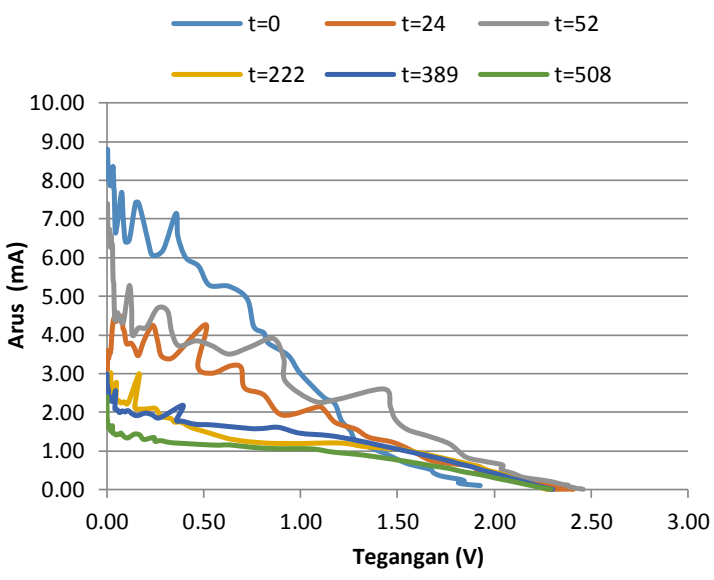

Gambar 8. Kurva I-V Life Time Sampel 3 (Scattering)

Pengujian life time modul surya menghasilkan karakteristik $\mathrm{V}_{\mathrm{OC}}, \mathrm{I}_{\mathrm{SC}}$, dan efisiensi modul surya terhadap waktu. Karakteristik $\mathrm{V}_{\mathrm{OC}}$ dan $\mathrm{I}_{\mathrm{SC}}$ modul surya sampel 2 (non-scattering) dapat dilihat pada Gambar 9

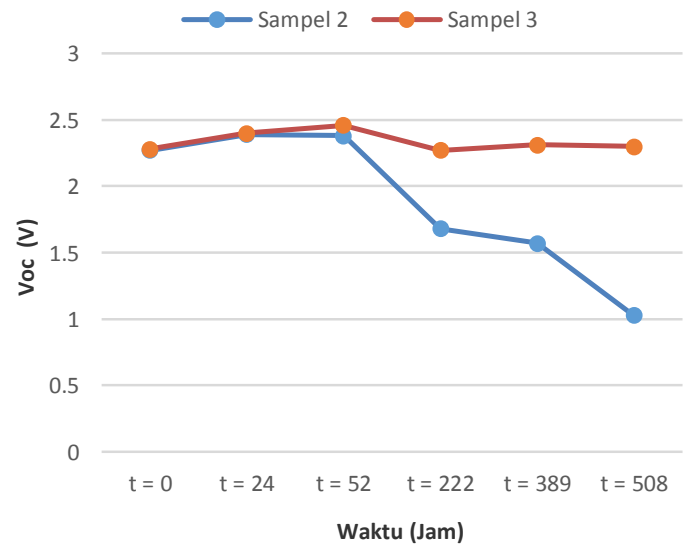

Gambar 9. Grafik $V_{\text {OC }}$ Sampel 2 (Non-Scattering) dan Sampel 3 (Scattering).

dan sampel 3 (scattering) dapat dilihat pada Gambar 10. Gambar 9 menjelaskan karakteristik life time dari $\mathrm{V}_{\mathrm{OC}}$ modul surya sampel 2 (non-scattering) dan sampel 3 (scattering), dapat dilihat bahwa grafik menunjukkan karakteristik life time yang berbeda baik pada awal pengujian namun mengalami penurunan yang drastis setelah pengujian 24 jam juga terhadap pengujian lainnya hingga pengujian 500 jam. Gambar 10 menjelaskan karakteristik life time $\mathrm{I}_{\mathrm{SC}}$ modul surya sampel 2 (non-scattering) yang terlihat penurunan nilai $\mathrm{I}_{\mathrm{sc}}$ yang drastis dari pengukuran awal dan modul surya sampel 3 (scattering), dapat dilihat bahwa grafik menunjukkan karakteristik life time yang cenderung stabil terhadap penurunannya yang bertahap hingga 500 jam pengujian modul surya.

Pengujian life time modul surya juga menghasilkan karakteristik efisiensi modul surya terhadap waktu, karakteristik efisiensi modul surya sampel 2 (nonscattering) dan sampel 3 (scattering) dapat dilihat pada Gambar 11. 


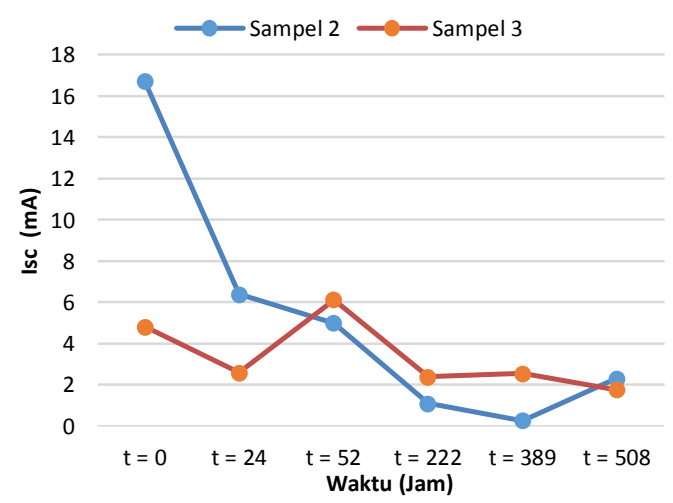

Gambar 10. Grafik ISC Sampel 2 (Non-Scattering) dan Sampel 3 (Scattering).

Gambar 11 menunjukkan efisiensi dari modul surya sampel 2 (non-scattering) dan sampel 3 (scattering). Dapat dilihat bahwa efisiensi yang ditunjukkan oleh modul surya sampel 2 (non-scattering) dan sampel 3 (scattering) sangat berbeda. Modul surya sampel 2 (non-scattering) menunjukkan efisiensi terbaiknya pada nilai $1 \%$ namun menunjukkan penurunan yang signifikan setelah pengukuran awal. Sedangkan modul surya sampel 3 (scattering) menunjukkan efisiensi terbaiknya sebesar $0,31 \%$ dan terlihat lebih stabil dengan penurunan bahkan kenaikan yang tidak terlalu signifikan.

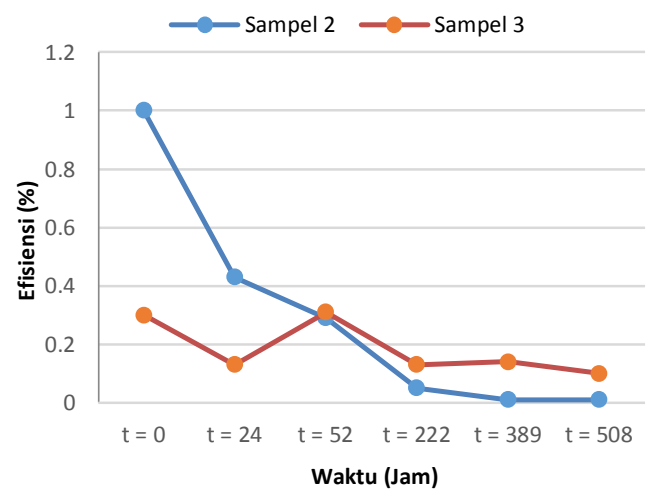

Gambar.11. Grafik Efisiensi Sampel 2 (Non-Scattering) Dan Sampel 3 (Scattering)

Berdasarkan hasil pengukuran karakteristik I-V dan life time yang telah diuraikan menunjukkan bahwa penambahan $\mathrm{TiO}_{2}$ scattering dapat mempengaruhi life time modul surya. Modul surya yang tidak menggunakan $\mathrm{TiO}_{2}$ scattering (Sampel 2) terlihat kurang stabil saat dibebani pada proses pengukuran. Sampel modul surya yang diberi $\mathrm{TiO}_{2}$ scattering yaitu sampel 3 cenderung lebih stabil dilihat dari kurva I-V yang ditunjukkan pada setiap pengukuran. Penggunaan scattering pada modul surya bertujuan untuk menambah karakteristik modul surya terhadap life time berpengaruh juga terhadap kekuatan modul surya terhadap beban yang diberikan ketika proses pengukuran.

Secara umum karakteristik I-V dan life time modul surya masih belum baik. Berdasarkan analisis dan pengamatan terhadap modul surya tersebut, hal ini dimungkinkan oleh tidak sempurnanya assembly sehingga terjadi kebocoran yang menyebabkan menguapnya pelarut elektrolit. Dengan adanya penguapan pelarut maka konsentrasi elektrolit dalam sel akan meningkat yang akan menyebabkan nilai Rs dan Rsh meningkat pula, sehingga mobilitas ion $\mathrm{I}^{-} / \mathrm{I}_{3}{ }^{-}$dan elektron menjadi lebih rendah. Hal ini selanjutnya akan berdampak pada terhambatnya regenerasi molekul pewarna (dye) oleh iodine, yang mengakibatkan eksitasi elektron terganggu sehingga arus yang dihasilkan menjadi lebih kecil. Terbukti pada modul surya sampel 1 yang mengalami kebocoran terparah dari pada modul lainnya. Dalam proses pabrikasi modul surya harus benar-benar hati-hati dan teliti terutama pada proses pencetakan glass frit pada substrat sebagai perekat antara elektroda kerja dan elektroda lawan pada proses assembly. Proses pelapisan $\mathrm{TiO}_{2}$ sub-mikron terhadap $\mathrm{TiO}_{2}$ partikel nano yang dilakukan, dapat juga berpengaruh terhadap hasil penelitian.

\section{KESIMPULAN}

Dari penelitian yang telah berhasil dilakukan, dapat disimpulkan bahwa pengujian life time yang dilakukan selama 500 jam, hasilnya menunjukkan bahwa modul surya dengan lapisan scattering dapat mempengaruhi karakteristik life time namun efisiensi yang didapatkan kurang baik yaitu sebesar $0,31 \%$ sedangkan modul surya dengan lapisan non-scattering menunjukkan efisiensi yang baik yaitu sebesar $1,83 \%$ namun karakteristik life time yang kurang baik. Karakterisasi life time terhadap modul surya berbasis pewarna menggunakan interkoneksi seri yang menggunakan $\mathrm{TiO}_{2}$ scattering terlihat lebih stabil dan memiliki life time yang lebih baik namun memiliki efisiensi yang kurang baik dari pada modul surya berbasis pewarna interkoneksi seri yang menggunakan $\mathrm{TiO}_{2}$ nonscattering

\section{UCAPAN TERIMA KASIH}

Penulis mengucapkan terima kasih kepada PPETLIPI yang telah memfasilitasi terlaksananya penelitian ini. Penulis juga mengucapkan terima kasih kepada para peneliti di Keltian Sel Surya PPET-LIPI Bandung yang telah memberikan bantuannya selama proses penelitian.

\section{DAFTAR REFERENSI}

[1] S. Hore, C. Vetter, R. Kern, H Smit, A. Hinsch, "Influence of scattering layers on efficiensi of dye-sensitized solar cells", Solar Energy Material and Solar Cells, vol. 90, pp. 1176-1188, 2006.

[2] B. O'regan and M. Gratzel, "A low-cost, high efficiency solar cell based on dye-sensitized colloidal $\mathrm{TiO}_{2}$ films", Nature, vol. 353, iss. 6346, pp. 737, 1991.

[3] L. S. Mende and M. Grätzel, "Pore-filling and its effect on the efficiency of solid-state dye-sensitized solar cell", Thin Solid Films, vol. 500, pp. 296-301, 2006.

[4] M. L. Huang, H. X. Yang, J. H. Wu, J. M. Lin, Z. Lan, P. J. Li, S. C. Hao, P. Han and Q. W. Jiang, "Preparation of a novel polymer gel electrolyte gel based on n-methyl-quinoline iodide and its application in quasi-solid-state dye-sensitized solar cell", J. Sol-Gel Sci. Techn, vol. 42 (27), pp. 65-70, 2007.

[5] G. P. Smestad and M. Grätzel, "Demonstrating electron and nanotechnology", J. Chem.Educ, vol. 75 (6), pp. 1- 6, 1998.

[6] A. F. Nogueira, C. Longo, M. A. De Paoli, "Polymers in dye sensitized solar cells: overview and perspectives", Coordination Chemistry Reviews, vol. 248, pp.1455-1468, 2004.

[11] L. Muliani and J. Hidayat, "Process design of interconnected grid z-type dye solar cell sub-modules", Research Center for Electronics and Telecommunication (PPET-LIPI), Bandung, Technical Report, 2013. 